\title{
学校給食における献立構成要素および 料理とその素材に関する研究
}

\author{
増 田和 雄, 早 川睦 月*1, 相川り急子"1, 澤山 茂 ${ }^{* 1}$ \\ 熊 谷 惟 明*2, 新 部 昭 夫*2, 川 端 晶 子*1 \\ 文部省体育局学校給食課, ${ }^{* 1}$ 東京農業大学農学部栄養学科, ${ }^{* 2}$ 東京農業大学電算機室
}

\section{Constituent Elements, Ingredients and Cooking Methods of School Lunches}

Kazuo Masuda, Mutsuki Hayakawa*1, Rieko Aikawa*1, Shigeru Sawayama*1,

Koreaki Kumagai*2, Akio Nibe ${ }^{* 2}$ and Akiko Kawabata*1

School Lunch Division, Physical Education Bureau, The Ministry of Education ;

${ }^{* 1}$ Department of Nutrition, Tokyo University of Agriculture ;

${ }^{* 2}$ Computer Center, Tokyo University of Agriculture

The constituent elements, ingredients and cooking methods employed in preparing 6,000 menus for school lunches were studied by "Analysis of relativity of elementary technologies". The following results were obtained.

1) As for the constituent pattern of menus, $18.3 \%$ consisted of one each main dish and side dish with staple food, $27.8 \%$ additionally included 2 to 3 side dishes, $12.8 \%$ additionally included soup, and $25.3 \%$ included dessert.

2) Bread was served as staple food with a slightly more frequency than rice, and the main dishes consisted of meat, fish, peas and beans, and egg in this order. The number of food items served per one meal ranged between 13.5 and 18.1 , and the number of dishes 2.22 and 2.81 .

3) As proteins served in the lunches, chicken was served most often, followed by chicken egg, pork, fried tofu-bean curd and ham. As green vegetables, carrot was served most followed by spinach, parsley, sweet pepper and tomato. Other vegetables served were onion, cabbage, cucumber, green onion and bean sprout.

4) The combination of onion and carrot was most frequently served $(3,108$ times) at the relativity of 0.4060 , followed by the combinations of potato and carrot, potato and onion, and carrot and pork. As regards the seasonings, the tendency observed was that salt and pepper was often used with vegetable oil, and soy sauce with sugar.

Jpn. J. Nutr., 47 ( 1 ) 13 24 (1989)

\section{緒言}

我が国の学校給食は, 明治22年山形県の小学校で貧困览童を対象として行ったのが，その起源であるとされ ている。しかし，昭和29年学校給食法が公布されてからは，学校教育の一環に位置づけされ，児童生徒にバラ ンスのとれた栄養豊かな食事を提供し, 健康の増進, 体位の向上を図り, さらに望ましい食習慣の形成と好ま

Key words : school lunches, constituent elements of menu, analysis of relationships among technology elements, frequency, relativity 学校給食, 献立構成要素, 要素技術連関分析, 出現頻度, 連関度 
しい人間関係の育成など, 児童生徒の心身の健全な発達に資するとともに，国民の食生活の改善に寄与するこ とを目的として，実施されてきている。

文部省より, 学校給食の所要栄養基準量および標準食品構成表が示され, 多用な食品によるバランスのとれ た栄養摂取が図られるよう指導され，ほほ満足すべき状態にあるが，献立の内容についての検討はあまりなさ れていない。

従来より, 食事の内容の検討には, 栄養素および食品群の種類と量のバランスに重点がおかれているが, お いしく, 魅力ある豊かな食事内容が期待されている現在, 学校給食においても, 献立構成の法則性1.22を考え

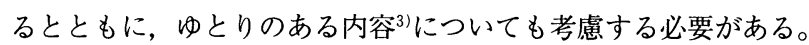

豊川ら ${ }^{4 \sim 6)}$ は，食生活論の展開や食生活指導の実践には，栄養素・料理・食品および食料の 4 つを要素とし た理論体系が重要であるが, 料理を要素とする理論体系が脆弱であることを指摘し，その構築の急務を力説し

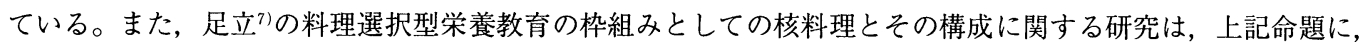
栄養教育の立場から新しい一石を投じたといえよう。

著者らは, 上記豊川の問題提起に対し, 深い関心をもつとともに, 料理を要素とした理論体系の構築に摸索 を続けているが，前報8)でフィリピンのメニューカレンダーを資料とし，要素技術連関解析の手法9)用いて， 献立における調理素材と調理法の相互関係について検討し，その特徵を抽出した。

要素技術連関解析 (Analysis of Relationships Among Technology Elements：ARATE) は, 複数の要素技 術からなる複合技術の構成と, 要素技術間の関係を解明する手法9)である。

本研究では，全国統一の所要栄養基準量および標準食品構成表のもとに，ほぼ同一価格で実施されている学 校給食の献立構成要素および料理とその素材について検討することを目的とした。近年，食文化や伝統的食生 活が見直され，学校教育の中でも関心がもたれているが，学校給食献立内容に地域的特徵が見出されるかどう かについても検討を行った。

\section{研 究 方 法}

\section{1. 資料}

文部省体育局学校給食課に報告された，昭和 $58 ， 59 ， 60$ 年度 5 月および11月の全国完全給食実施校の $1 / 50$ に当たる, 学校給食栄養報告書の延給食献立 6,000 件を資料とし, 報告書の「様式 $1 」 に$ に記されている献立名 および使用材料名の項目を研究対象として用いた。

\section{2. 解析の考え方}

(1) 献立構成要素

歴史と文化によって培われ，発達してきた料理様式別献立の経緯や，健康づくりのための食事計画としての 献立構成要素を考える時，日常食の献立は表 1 に示すように, “序論”, “本論”, “結論”から構成されるのが 最も望ましい'と考えられるので，以下のように定義し，学校給食の献立内容の解析に採用した。

献立構成要素における “序論”とは，食欲をよび起こすことを目的とし，前菜や汁物が用いられる。“本論” とは, 主要な栄養素を摃取することを目的とし, 主食と副食からなり, 副食は主菜と副菜から構成される。す なわち，主食，主菜抢よび副菜が核料理7といわれているものである。“結論”とは，“序論”や“本論”の栄 盖素の不足を補うとともに，味覚・生理的および精神的満足感を与える目的をもっていて，デザートがその役 割を果たす。 
(2) 調理素材と 表 1 献立構成要素

しての食品の出現 頻度

図1のように, 調理素材としての 食品の出現頻度, 共出現頻度および 連関度について解 析を行った。

\section{3. 解析方法}

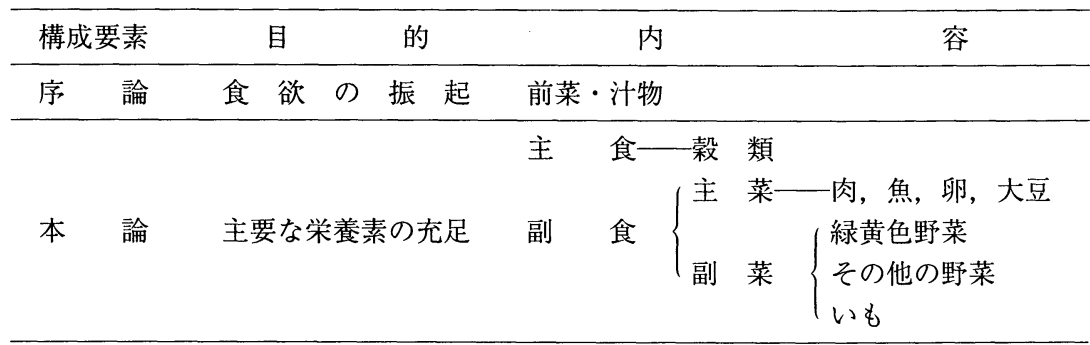

\begin{tabular}{cc}
\hline 栄養素の補 充 \\
結 論 \\
\end{tabular}

解析には, 吉村 ${ }^{9}$ の要素技術連関解析法を一 部修正して用いた。調理素材としての食品は, 四訂食品成分表に基づいて10進 4 桁のファセッ ト分類表を作成してコード化し，データベース を作成した。食品コードは, 四訂食品成分表の 食品群の名称を用いた。

各献立を表すフェースコードと，それに付与

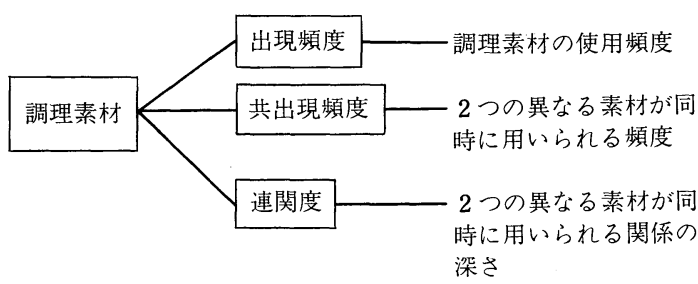

図 1 調理素材としての食品の出現頻度

されたインディクスを単位レコードとし，学校給食栄養報告書に集録されている全ての料理を含むデータベー スを作成して, コンピュータ（FACOM M-360）を用いて解析し, 献立構成要素別出現頻度, 献立中の料理 とその素材としての食品の種類と出現頻度について検討を行った。

\section{結果および考察}

\section{1. 献立構成要素}

資料として用いた学校給食の地域別延献立数を表 2 に示した。合計給食延献立数は，6,000件である。

(1) 献立構成要素別出現頻度

表 3 に献立構成要素別出現頻度を示した。本論の核料理といわれる主食, 主菜および副菜が 1 品からなる献 立は，全国平均で最も頻度が高く，18.3\%，それにデザート付きが 2 位で $15.6 \%$ ，汁物付きが $12.8 \%$ を占めて いた。また，全体でデザート付きの献立が $25.3 \%$ 占めていた。特に，主食，主菜および副菜の各 1 品ずつか らなるシンプルな献立の出現頻度の高いのは, 近畿, 四国, 九州・沖縄, つづいて中国地域の西日本に拀いて であった。デザートや汁物付きも加えて, 核料理といわれる主食, 主菜および副菜の整っている献立は $55 \%$ に 達し，望ましい献立作成への努力の跡をうかがうことができる。

食品産業センターのアンケート ${ }^{10}$ によると，子どもたちがふだん食生活に望んでいることの第 2 番目に, $39.2 \%$ という高率で, “夕食の後にデザートが欲しい”という希望がでているが, 学校給食においてもデザー トの残量が相対的に少ない(1) ことから，デザートに対する子どもの関心度の高いことがうかがえる。

学校給食の献立作成やその表現法の研究12) も熱心に行われているが，1日1日の献立が，子どもたちに何 を語りかけるのか，栄養素や調理素材の説明ばかりでなく，豊かな心を育て，楽しく，おいしくいただくため の土夫が期待されている ${ }^{13)}$ 。 
(2) 主食

米飯給食の正式導入は昭和 51 年度からであるが, 約 10 年を経た今回の対象となった 6,000 件の献立中, パ ンは $50.1 \%$ ，米飯は $38.9 \%$ で，残りがめんであった。 主食の材料がいずれであっても，牛乳が必ず供される ところに我が国の学校給食の特徴があり, カルシウム 摂取に大きく寄与していると考えられる。

全国レベルにおける主食の料理名の出現頻度10位ま でを表 4 に示した。パン料理では 1 位から 8 位まで, 米飯料理では1位のではんのみが独立した主食としで。 米飯料理では 1 位のごはんのみが独立した主食として取り扱われている。その他の主食料理は, 主食と副食が 合体した形であるが，主食としてのみカウントした。

(3) 副食

主菜料理の主材料別出現頻度を図 2 に示した。肉料理の出現頻度が最も高く,つづいて魚料理であり, 卵料 理と豆料理は地域によって順位が逆転しているところもあった。

全国レベルの主菜料理名の出現頻度を表 5 に示した。肉を主材料とした料理名の分布は広く, 1 位のハン バーグが $8.2 \%$ ，鶏空揚げが 2 位で $7.1 \%$ でったが，魚を主材料とする料理名では，魚種の違いは分類してい ないことにもよるが, フライが $25 \%$ という高出現頻度を示し，魚料理の $1 / 4$ はフライであった。卵料理では，

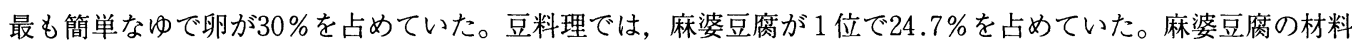
は豆腐とひき肉の組み合わせであるが，料理名と重量比の多いことから，豆腐の項に分類した。

全国レベルの副菜の料理名の出現頻度を表 6 に示した。野菜料理では，生野菜という料理名が $25.6 \%$ 高出 現頻度を示していた。和え物やサラダ料理では，和風の和え物よりもサラダの出現頻度が高く，2倍に迫る高 率を示していた。

出現頻度はあまり高くないが, 主菜や副菜の料理名に地域別特徵がみられ，郷土料理を学校給食の献立に採 用し，食文化への 関心を高めようと する傾向が認めら れた。

(4) 汁物とデ ザート

汁物の出現頻度 は全国レベルで 12.8\%であり, あ まり高くないのは, 毎回必ず牛乳が供 されるためである と考えられる。汁 物の料理名を表 7

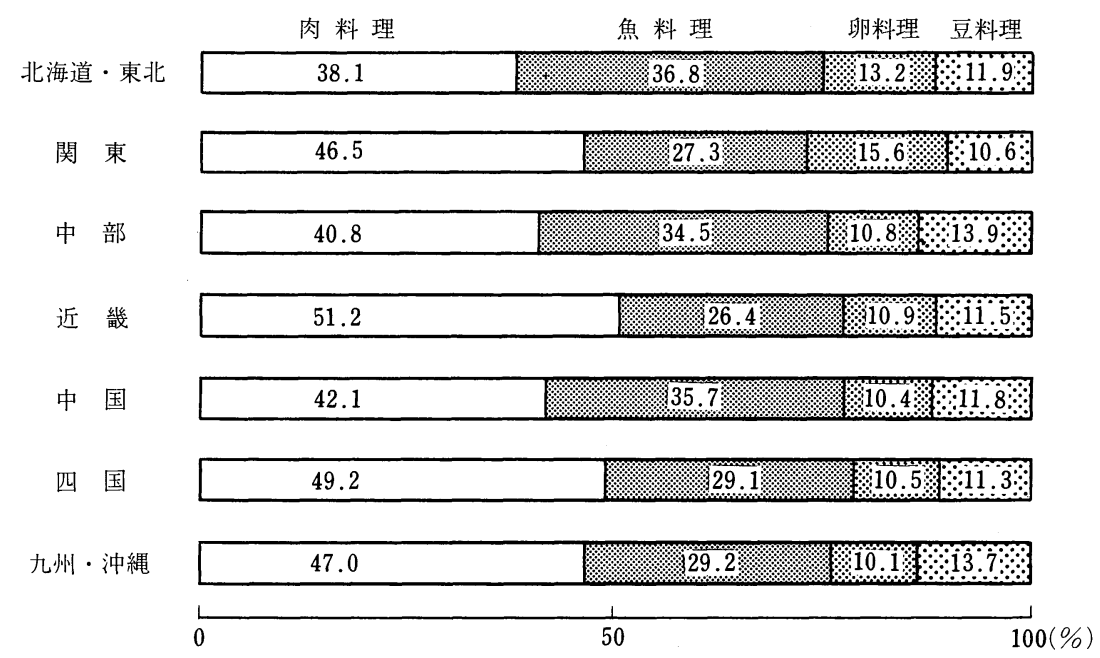

図 2 主菜料理の出現頻度 
表 3 献立構成要素別出現頻度

\begin{tabular}{|c|c|c|c|c|c|c|c|}
\hline \multirow{3}{*}{ 地 } & \multirow{3}{*}{$\begin{array}{l}\text { 順 } \\
\text { 位 }\end{array}$} & \multirow{3}{*}{$\begin{array}{l}\text { 序論 } \\
\text { (汁物) }\end{array}$} & \multicolumn{2}{|l|}{ 本 } & 合 & \multirow{3}{*}{ 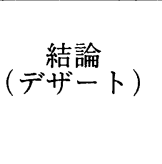 } & \multirow{3}{*}{$\begin{array}{c}\text { 地域別献立 } \\
\text { 数に対す } \\
\text { 比率 } \\
(\%) \\
(\%)\end{array}$} \\
\hline & & & \multirow{2}{*}{ (主食·主牛乳) } & 副 & 食 & & \\
\hline & & & & 主菜 & 副菜 & & \\
\hline \multirow{5}{*}{ 北海道 } & 1 & & 0 & 0 & 0 & \multirow[t]{4}{*}{0} & 14.9 \\
\hline & 2 & & 0 & 0 & 0 & & 11.8 \\
\hline & 3 & 0 & 0 & 0 & 0 & & 7.9 \\
\hline & 4 & & 0 & 0 & $\bigcirc \bigcirc$ & & 5.8 \\
\hline & 5 & 0 & 0 & 0 & & 0 & 5.6 \\
\hline \multirow{5}{*}{ 関 } & 1 & & 0 & 0 & 0 & \multirow{4}{*}{$\begin{array}{l}\bigcirc \\
\bigcirc\end{array}$} & 16.8 \\
\hline & 2 & & 0 & 0 & & & 13.4 \\
\hline & 3 & & 0 & 0 & 0 & & 12.6 \\
\hline & 4 & & 0 & 0 & 00 & & 9.3 \\
\hline & 5 & & 0 & & 0 & 0 & 4.5 \\
\hline \multirow{5}{*}{ 中 } & 1 & & 0 & 0 & 0 & \multirow[t]{4}{*}{0} & 16.9 \\
\hline & 2 & & 0 & 0 & 0 & & 11.4 \\
\hline & 3 & 0 & 0 & 0 & 0 & & 10.2 \\
\hline & 4 & & 0 & 0 & 00 & & 10.0 \\
\hline & 5 & & 0 & 0 & & 0 & 6.9 \\
\hline \multirow{4}{*}{ 近 } & 1 & & 0 & 0 & 0 & \multirow{5}{*}{$\begin{array}{l}0 \\
0\end{array}$} & 27.6 \\
\hline & 2 & & 0 & 0 & & & 12.8 \\
\hline & 3 & & 0 & 0 & 0 & & 12.6 \\
\hline & 4 & 0 & 0 & 0 & & & 7.5 \\
\hline 畿 & 5 & 0 & 0 & 0 & 0 & & 7.1 \\
\hline \multirow{4}{*}{ 中 } & 1 & & 0 & 0 & 0 & \multirow[t]{4}{*}{$\bigcirc$} & 18.3 \\
\hline & 2 & & 0 & 0 & $\bigcirc$ & & 16.7 \\
\hline & 3 & & 0 & 0 & $\bigcirc \bigcirc$ & & 12.2 \\
\hline & 4 & 0 & 0 & 0 & 0 & & 9.2 \\
\hline 国 & 5 & & 0 & 0 & & 0 & 8.4 \\
\hline & 1 & & 0 & 0 & 0 & & 23.1 \\
\hline & 2 & & 0 & 0 & $\bigcirc$ & 0 & 23.1 \\
\hline 国 & 3 & & 0 & 0 & $\bigcirc \bigcirc$ & & 10.9 \\
\hline & 4 & & 0 & 0 & & 0 & 8.8 \\
\hline & 5 & 0 & 0 & 0 & 0 & & 5.1 \\
\hline & 1 & & 0 & 0 & 0 & & 20.8 \\
\hline & 2 & & 0 & 0 & & 0 & 13.8 \\
\hline 九 州・沖 縄 & 3 & & 0 & 0 & $\bigcirc$ & $\bigcirc$ & 11.4 \\
\hline & 4 & $\bigcirc$ & 0 & $\bigcirc$ & & & 9.6 \\
\hline & 5 & 0 & 0 & $\mathrm{O}$ & 0 & & 5.7 \\
\hline & 1 & & $\bigcirc$ & 0 & 0 & & 18.3 \\
\hline & 2 & & $\bigcirc$ & $\bigcirc$ & $\bigcirc$ & $\bigcirc$ & 15.6 \\
\hline 全 国 平 均 & 3 & 0 & 0 & $\bigcirc$ & 0 & & 12.8 \\
\hline & 4 & & 0 & 0 & & 0 & 9.8 \\
\hline & 5 & & 0 & 0 & $\bigcirc \bigcirc$ & & 8.4 \\
\hline
\end{tabular}


表 4 主食の料理名の出現頻度

\begin{tabular}{|c|c|c|c|c|c|c|c|c|}
\hline \multicolumn{2}{|c|}{ 分 } & \multicolumn{2}{|c|}{ 類 } & \multirow{2}{*}{$\begin{array}{c}\text { 順位 } \\
1\end{array}$} & \multicolumn{2}{|l|}{ 料 理 名 } & \multirow{2}{*}{$\frac{\text { 出現頻度 }}{735}$} & \multirow{2}{*}{$\frac{\text { 出現率 }(\%)}{31.7}$} \\
\hline & & & & & パ & ン & & \\
\hline & & & & 2 & 食パ & ン & 334 & 14.4 \\
\hline & & & & 3 & $コ \%$ ペ パ & ン & 330 & 14.2 \\
\hline & & & & 4 & バ夕ーロー & ル & 122 & 5.3 \\
\hline \multirow[t]{10}{*}{ パ } & ン & 料 & 理 & 5 & ぶ ど う パ & ン & 95 & 4.1 \\
\hline & & & & 6 & ミルク パ & ン & 73 & 3.1 \\
\hline & & & & 7 & 黒 パ & ン & 71 & 3.0 \\
\hline & & & & 8 & 小 型 パ & ン & 68 & 2.9 \\
\hline & & & & 9 & サンドウィッ & チ & 61 & 2.6 \\
\hline & & & & 10 & セルフサン & ド & 59 & 2.5 \\
\hline & & & & 1 & ごは は & h & 1,076 & 49.8 \\
\hline & & & & 2 & カレーライ & ス & 269 & 12.4 \\
\hline & & & & 3 & わかめごは & h & 103 & 4.8 \\
\hline & & & & 4 & 麦ごは & h & 86 & 4.0 \\
\hline \multirow[t]{10}{*}{ 米 } & 飯 & 料 & 理 & 5 & たけのこごは & L & 83 & 3.8 \\
\hline & & & & 6 & ピ ラ & フ & 61 & 2.8 \\
\hline & & & & 7 & 五 目 ごは & h & 36 & 1.7 \\
\hline & & & & 8 & かゃくごは & $h$ & 34 & 1.6 \\
\hline & & & & 9 & ハヤシライ & ス & 31 & 1.4 \\
\hline & & & & 9 & 豆ごは & L & 31 & 1.4 \\
\hline & & & & 1 & 焼 き そ & ば & 183 & 20.2 \\
\hline & & & & 2 & $ミ-ト ソ-$ & ス & 134 & 15.0 \\
\hline & & & & 3 & 煮込みうど & h & 51 & 5.7 \\
\hline & & & & 4 & $\overline{5}-x$ & ン & 48 & 5.4 \\
\hline \multirow[t]{6}{*}{ め } & h & 料 & 理 & 5 & カレーうど & h & 47 & 5.3 \\
\hline & & & & 6 & きつねうど & h & 42 & 4.7 \\
\hline & & & & 7 & ナ ポリ 多 & ン & 36 & 4.0 \\
\hline & & & & 8 & 天ぷらうど & L & 35 & 3.9 \\
\hline & & & & 9 & ス パ ゲ テ & イ & 28 & 3.1 \\
\hline & & & & 10 & 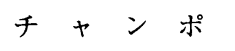 & ン & 23 & 2.6 \\
\hline
\end{tabular}

に示したが，味噌汁が $24.3 \%$ で約 $1 / 4$ を占めていた。

デザートの料理名を表 8 に示したが，55\%が生の果物であった。

(5) 献立中の料理数

牛乳および組み合わせになっている主食を除いた地域別の 1 回の献立中の料理数（おかずの数）を図 3 に示 した。

北海道・東北，中部，中国および四国地域では 3 品が $45 \%$ 以上を占め，関東，近畿および九州・沖縄地域で は 2 品が $50 \%$ 前後であった。なお，平均料理数は中部が最も多く，2.81であった。北海道・東北 2.72 , 四国 2.66 , 中国 2.65 , 関東 2.54 , 近畿 2.35 , 九州・沖縄 2.22 の順であった。

\section{2. 食品の出現頻度}

(1) 食品数

地域別出現頻度を表 9 に示した。 
表 5 主菜の料理名の出現頻度

\begin{tabular}{|c|c|c|c|c|c|c|c|c|}
\hline 分 & & 類 & 順位 & & 料 理 名 & & 出現頻度 & 出現率 (\%) \\
\hline \multirow{10}{*}{ 肉 } & \multirow{10}{*}{ 料 } & \multirow{10}{*}{ 理 } & 1 & 八 & ン バ - & グ & 152 & 8.2 \\
\hline & & & 2 & 鷄 & 空＼cjkstart揚 & げ & 131 & 7.1 \\
\hline & & & 3 & クリ & Jームシチュ & - & 107 & 5.8 \\
\hline & & & 4 & 肉 & じゃ & が & 106 & 5.7 \\
\hline & & & 4 & 八 & 宝 & 菜 & 106 & 5.7 \\
\hline & & & 6 & 旨 & & 煮 & 88 & 4.8 \\
\hline & & & 7 & 肉 & 団 & 子 & 81 & 4.4 \\
\hline & & & 8 & と & L 力 & ッ & 80 & 4.3 \\
\hline & & & 8 & 焼 & き & 肉 & 80 & 4.3 \\
\hline & & & 10 & 酢 & & 豚 & 71 & 3.8 \\
\hline \multirow{10}{*}{ 魚 } & \multirow{10}{*}{ 料 } & \multirow{10}{*}{ 理 } & 1 & 魚 & ᄀ ラ & 1 & 340 & 25.1 \\
\hline & & & 2 & 煮 & 干 & L & 90 & 6.7 \\
\hline & & & 3 & 焼 & き & 魚 & 83 & 6.1 \\
\hline & & & 4 & 天 & ぷ & 5 & 74 & 5.5 \\
\hline & & & 5 & 竜 & 田＼cjkstart揚 & げ & 72 & 5.3 \\
\hline & & & 6 & お & で & $h$ & 65 & 4.8 \\
\hline & & & 7 & 空 & 揚 & げ & 59 & 4.4 \\
\hline & & & 8 & 照 & り 焼 & き & 50 & 3.7 \\
\hline & & & 9 & 南 & 蛮 漬 & け & 40 & 3.0 \\
\hline & & & 10 & 小 & & 魚 & 38 & 2.8 \\
\hline \multirow{10}{*}{ 卵 } & \multirow{10}{*}{ 料 } & \multirow{10}{*}{ 理 } & 1 & $\Phi$ & で & 卵 & 152 & 30.1 \\
\hline & & & 2 & 卵 & と & じ & 59 & 11.7 \\
\hline & & & 3 & オ & ム $レ$ & ツ & 47 & 9.3 \\
\hline & & & 4 & 卵 & 焼 & き & 45 & 8.9 \\
\hline & & & 5 & 厚 & 焼 き & 卵 & 30 & 5.9 \\
\hline & & & 6 & 炒 & $\eta$ & 卵 & 27 & 5.3 \\
\hline & & & 7 & 目 & 玉＼cjkstart焼 & き & 25 & 5.0 \\
\hline & & & 8 & 八 & 厶 I & グ & 13 & 2.6 \\
\hline & & & 9 & 卵 & フ ラ & 1 & 12 & 2.4 \\
\hline & & & 10 & 巣 & ご もり & 卵 & 10 & 2.0 \\
\hline \multirow{10}{*}{ 豆 } & \multirow{10}{*}{ 料 } & \multirow{10}{*}{ 理 } & 1 & 麻 & 婆 豆 & 腐 & 124 & 24.7 \\
\hline & & & 2 & 煮 & & 豆 & 75 & 14.9 \\
\hline & & & 3 & 納 & & 豆 & 54 & 10.8 \\
\hline & & & 4 & 炒 & $\eta$ 豆 & 腐 & 42 & 8.4 \\
\hline & & & 5 & 大 & 豆 磯 & 煮 & 33 & 6.6 \\
\hline & & & 6 & j & の & 花 & 23 & 4.6 \\
\hline & & & 7 & 五 & 目 & 豆 & 12 & 2.4 \\
\hline & & & 8 & 冷 & p & $こ$ & 11 & 2.2 \\
\hline & & & 9 & 枝 & & 豆 & 8 & 1.6 \\
\hline & & & 10 & 豆 腐 & 腐 の 中華 & 煮 & 6 & 1.2 \\
\hline
\end{tabular}

調味料を除いた 1 回に食べている食品数は, 関東が18.1で最も多く, つづいて中部 17.3 , 近畿 14.7 , 中国 16.3, 九州・沖縄 15.6, 四国 15.9, 北海道・東北 13.5の順となっていた。健康づくりのための食生活指 針 ${ }^{33}$ に示されている 1 日 30 食品の約 $1 / 2$ を学校給食で撕取していることになる。 
表 6 副菜の料理名の出現頻度

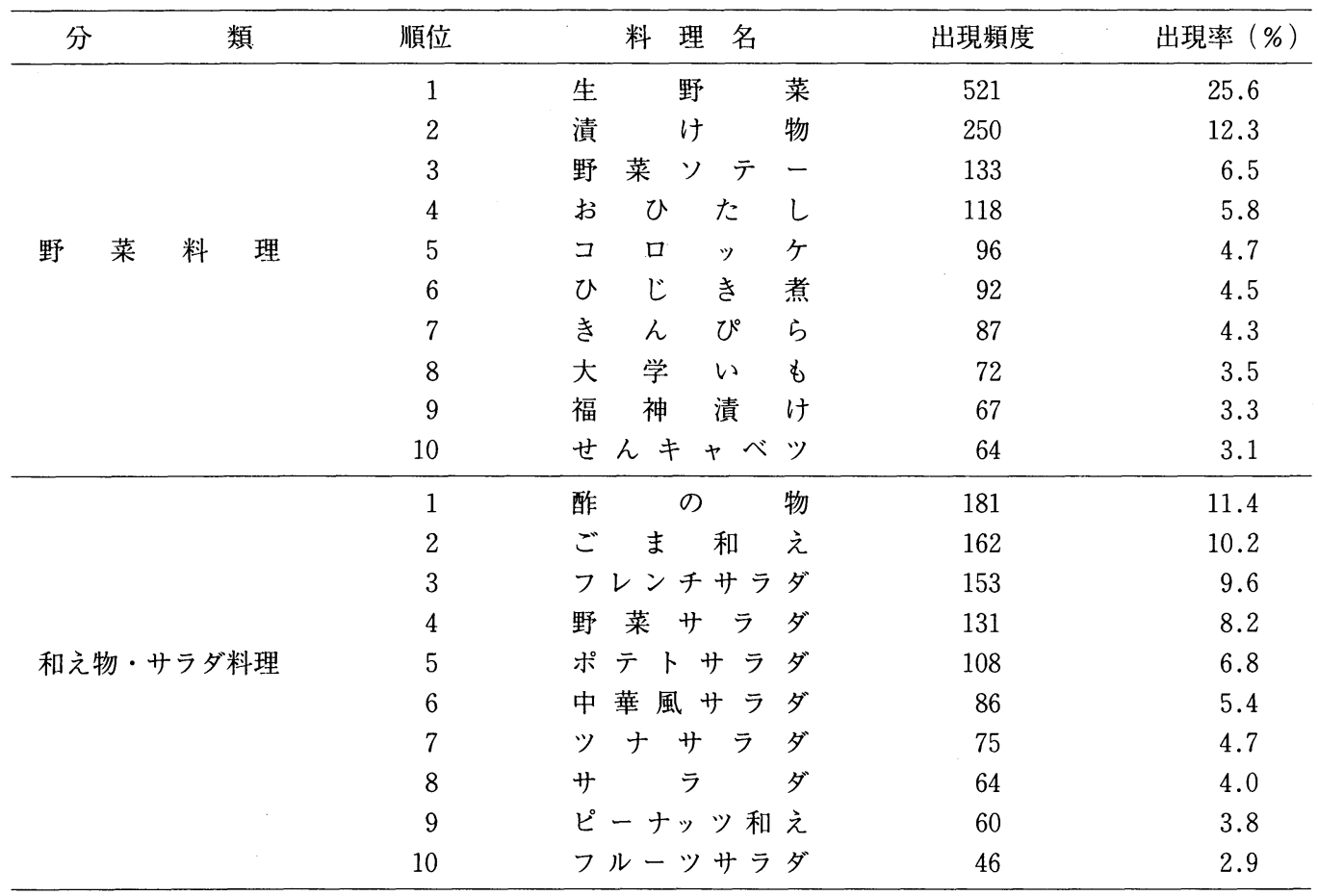

表 7 汁物の料理名の出現頻度

\begin{tabular}{|c|c|c|c|c|c|}
\hline 分 & 類 & 順位 & 料 理 名 & 出現頻度 & 出現率 (\%) \\
\hline \multirow{10}{*}{ 汁 } & \multirow{10}{*}{ 物 } & 1 & 噌 & 421 & 24.3 \\
\hline & & 2 & か き 卵 汁 & 153 & 8.8 \\
\hline & & 3 & 豚 & 111 & 6.4 \\
\hline & & 4 & L 汁 & 105 & 6.1 \\
\hline & & 5 & 卵 ス - プ & 95 & 5.5 \\
\hline & & 6 & 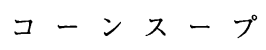 & 94 & 5.4 \\
\hline & & 7 & 野 菜 ス & 88 & 5.1 \\
\hline & & 8 & 中華 ス - プ & 77 & 4.4 \\
\hline & & 9 & ワンタンスープ & 72 & 4.2 \\
\hline & & 10 & $け ん \hbar ん$ 汁 & 65 & 3.8 \\
\hline
\end{tabular}

（2）調理素材としての食品の出現頻度

核料理に用いられている主な食品の出現頻度を表10に示した。

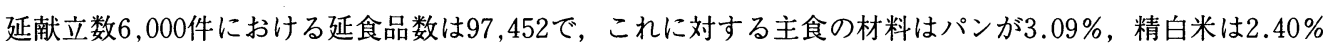
であった。主菜の材料では, 鷄肉, 䳕卵, 豚肉, 油揚げ・生揚げ，八ムの順に頻度が高かった。鶏肉につづい て鷄卵が第 2 位の出現頻度であるにもかかわらず，図 3 の主菜料理の主材料別出現頻度では全国的にみて第 4 位となっているのは，鶏卵の多様な調理性によるもので，副材料としての用途が多いためである。 副菜の材料である緑黄色野菜では，いずれの地域もにんじんの出現頻度が 1 位を占め，ほうれん草，パセリ， 
表 8 デザートの料理名の出現頻度

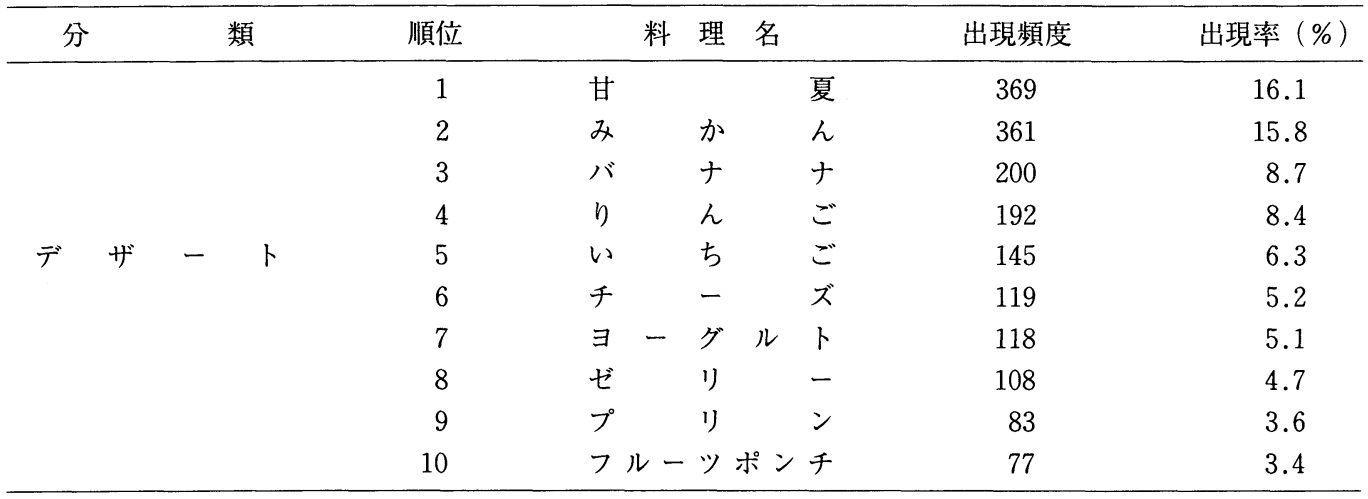

表 9 地域別の食品出現頻度

\begin{tabular}{|c|c|c|c|c|c|c|}
\hline \multirow{2}{*}{\multicolumn{2}{|c|}{ 地 }} & \multirow{2}{*}{\multicolumn{2}{|c|}{ 域 }} & \multirow{2}{*}{ 給食延献立数 } & \multicolumn{2}{|c|}{ 食品出現頻度 } \\
\hline & & & & & 延食品数 & 食品数/回 \\
\hline 北 & 海 道 & 東 & 北 & 720 & 9,723 & 13.5 \\
\hline 関 & & & 東 & 1,340 & 24,299 & 18.1 \\
\hline 中 & & & 部 & 1,174 & 20,327 & 17.3 \\
\hline 近 & & & 畿 & 809 & 11,926 & 14.7 \\
\hline 中 & & & 国 & 827 & 13,452 & 16.3 \\
\hline 四 & & & 国 & 294 & 4,685 & 15.9 \\
\hline 九 & 州· & 沖 & 縄 & 836 & 13,040 & 15.6 \\
\hline 合 & 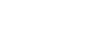 & & 計 & 6,000 & 97,452 & $15.9^{*}$ \\
\hline
\end{tabular}

* 平均

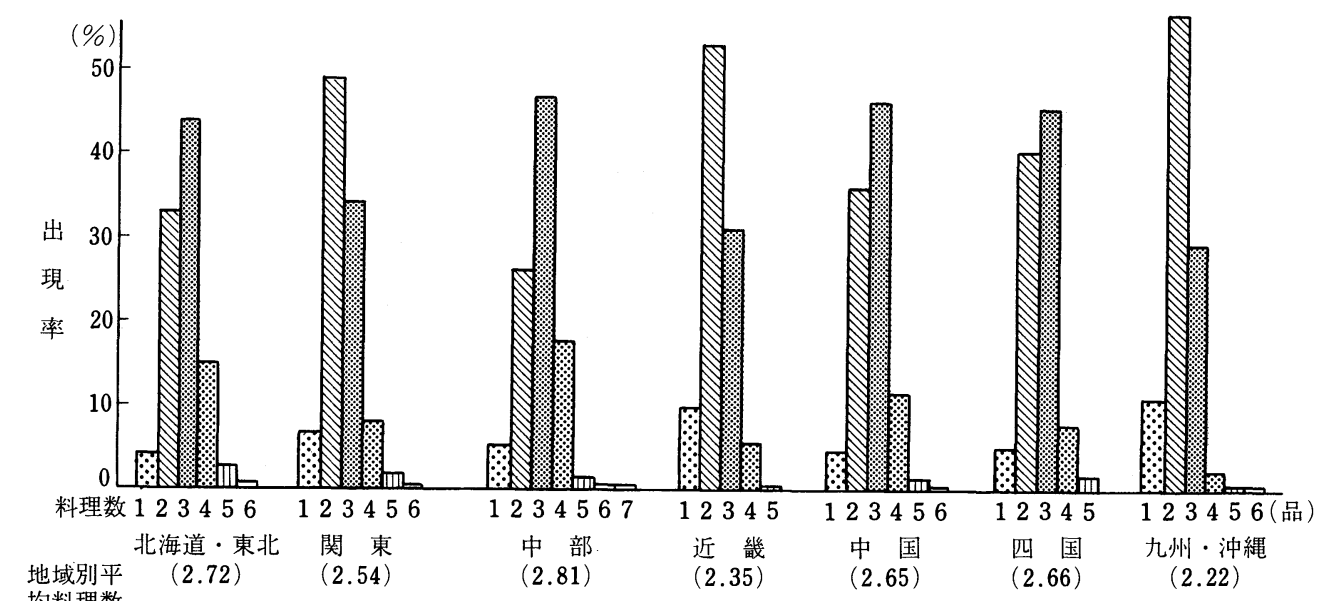

図 31 回の献立の料理数（全国平均料理数 2.56)

ピーマン, トマトが上位 5 位までを占めていた。特に,にんじんの 6,032 という出現頻度は給食延献立数を上 回り, 1 回の給食献立中, 2 品以上の料理に用いられていることを示している。その他の野菜では, いずれの 
表 10 核料理に用いられている主な食品の出現頻度

\begin{tabular}{|c|c|c|c|c|c|c|c|}
\hline 構 & 成 要 & 素 & 食 & & 品 & 出現頻度 & 出現率* (\%) \\
\hline \multirow[t]{2}{*}{ 主 } & \multirow{2}{*}{\multicolumn{2}{|c|}{ 食 }} & パ & & \multirow{2}{*}{$\begin{array}{l}\text { ン } \\
\text { *⿻丷木 }\end{array}$} & 3,007 & 3.09 \\
\hline & & & 精 & 白 & & 2,339 & 2.40 \\
\hline \multirow[t]{18}{*}{ 副 } & 食 & & & & & & \\
\hline & 主 & 菜 & 鶏 & 肉 & & 2,134 & 2.19 \\
\hline & & & 鶏 & 卵 & & 2,124 & 2.18 \\
\hline & & & 豚 & 肉 & & 1,949 & 2.00 \\
\hline & & & 油揚 げ & • 生揚 げ & & 1,052 & 1.08 \\
\hline & & & 八 & 么 & & 799 & 0.82 \\
\hline & 副 & 菜 & 緑＼cjkstart黄 & 色 野 菜 & & & \\
\hline & & & に & ん じ & $h$ & 6,032 & 6.19 \\
\hline & & & ほ & うれん & 草 & 867 & 0.89 \\
\hline & & & パ & 七 & リ & 594 & 0.61 \\
\hline & & & ピ & $-\quad \checkmark$ & ン & 419 & 0.43 \\
\hline & & & $r$ & ₹ & ト & 204 & 0.21 \\
\hline & & & その他 & せの野 菜 & & & \\
\hline & & & た & まね & ぎ & 3,713 & 3.81 \\
\hline & & & キ & ヤ ベ & ッ & 2,300 & 9.36 \\
\hline & & & き & う & $\eta$ & 1,608 & 1.65 \\
\hline & & & ね & & ぎ & 1,530 & 1.57 \\
\hline & & & 8 & p & L & 838 & 0.86 \\
\hline
\end{tabular}

注） 延献立数 6,000 件

* 延食品数 97,452 に対する出現率

地域も 1 位たまねぎ， 2 位キャベツであった。セロリーは香りが強いので，好き・嫌いのはっきりしている野 菜の 1 つと考えられているが, 北海道・東北および四国を除く 5 地域で 7 位に出現していた。流通機構の発達 した現在, 出現頻度の上位の生鮮野菜類に地域的な差は認められなかった。

(3) 食品の共出現頻度と連関度

共出現頻度 ${ }^{9}$ とは，2つの異なる素材が同時に用いられる料理の数である。また, 連関度9 とは, 2 つの素 材が同時に用いられる関係の深さを示し，次式によって求められる。

$$
\mathrm{R}=\mathrm{FA} \cdot \mathrm{B} /(\mathrm{FA}+\mathrm{FB}-\mathrm{FA} \cdot \mathrm{B})
$$

ここで, $\mathrm{R}$ は連関度, FA は素材 A の出現頻度, FB は素材 B の出現頻度であり, FA・B は素材 $\mathrm{A}$ と B の共 出現頻度である。

食品の共出現頻度と連関度を検討し，連関度の高い順に10位までを表11に示した。

野菜では，たまねぎとにんじんが0.4606という高い連関度を示し，つづいて，じゃがいもとたまねぎ，キャ ベッときゅうり,じゃがいもとにんじんなどの連関度が高かった。また, 精白米と強化米の連関度も, 0.4267 と高く, 精白米を用いる $43 \%$ 強に強化米が加えられていることになる。

調味料では，こしょうや食塩は植物油と，しょうゆは上白糖と高い連関度を示していた。

要 約

学校給食6,000件の献立における構成要素および料理とその素材としての食品の出現頻度の解析を行い, 次 
表 11 食品の共出現頻度と連関度

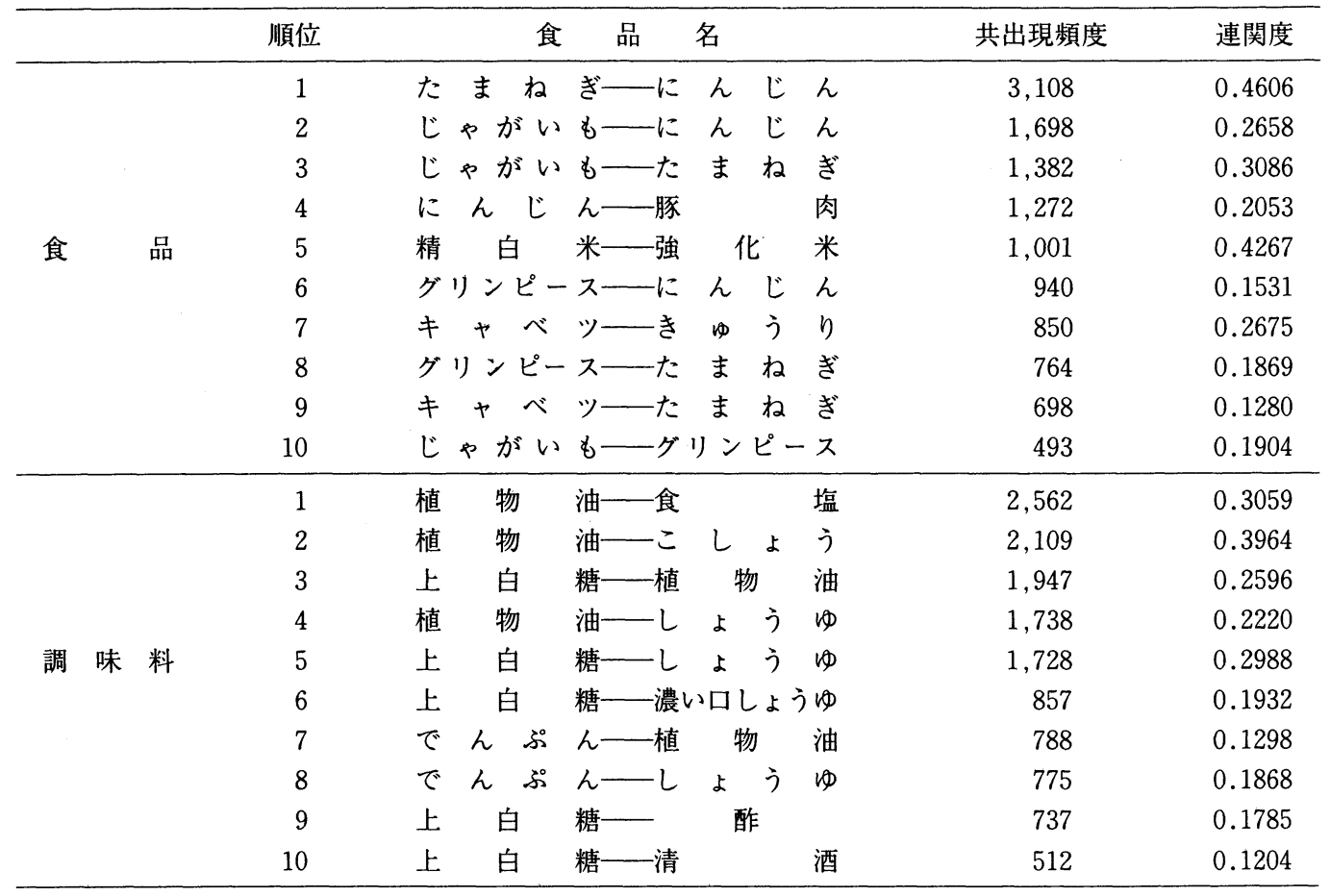

のような結果を得た。

1）献立構成パターンでは, 核料理といわれる主食, 主菜および副菜が 1 品からなるものが $18.3 \%$, 副菜 2 ～ 3 品のものを加えると $27.8 \%$, 汁物付きが $12.8 \%$, デザート付きが $25.3 \%$ であった。

2）主食料理の出現頻度では, パン料理が米飯料理をやや上まわり, 主菜では, 肉, 魚, 豆, 卵料理の順で あった。1 回の給食に用いられる食品数は13.5 18.1であり, 料理数は2.22 2.81であった。

3）食品の出現頻度は，たん白質食品では，鶏肉, 鶏卵, 豚肉, 油揚げ・生揚げ，八ムの順，緑黄色野菜で は, にんじん, ほうれん草, パセリ, ピーマン, トマトの順, その他の野菜では, たまねぎ, キャベッ, きゅ うり,ねぎ，もやしの順で高かった。

4）調理素材の共出現頻度では，たまねぎとにんじんが3,108回であり，連関度は0.4606が求められた。つ づいて，じゃがいもとにんじん，じゃがいもとたまねぎ，にんじんと豚肉であった。また，調味料の連関度か ら，塩やこしょうは植物油と，しょうゆは砂糖と併用される傾向にあることが認められた。

稿を終えるにあたり, データ処理にご協力いただいた東京農業大学農学部栄養学科調理学研究室の学生の皆 様に心より感謝申し上げる。

なお, 本研究は, 昭和 60,61 年度東京農業大学総合研究所一般プロジェクト研究費の助成によって行われた ものである。

本研究の一部は, 第42回日本栄養・食糧学会総会（大阪）において報告した。 
1）東佐與子：世界人は如何に食べつつあるか一各国比較調理術一, p.287（1954）東京創元社

2) Savarin, B. : Physiologie du Gout, p.23 (1965) Julliaid, Paris

3）厚生省保健医療局健康增進栄養課編：健康づくりのための食生活指針, p.5（1985）第一出版

4）豊川裕之：栄養学雑誌，42, 323 (1984)

5）豊川裕之：栄養日本，28，357（1985）

6）福場博保，豊川裕之編著：食生活論，p.179（1988）光生館

7）足立己幸：民族衛生，50，50（1984）

8）川端晶子, 澤山 茂, Lutgarda, S. P. : 栄養学雑誌, 43, 289 (1985)

9）吉村典夫：ドクメン ケンキュウ, 30, 160 (1980)

10）食品産業センター編：新人類の食生活, p.142（1987）食品産業センター

11）横浜市学校栄養士研究会：学校給食はいま, 日本の食生活, p.40（1986）全国食糧振興会

12）日本体育・学校健康センター：昭和62年度学校給食調理技術指導者養成講習会テキスト, p.1（1987）

13）川戸喜美枝：千葉大学教育学部附属小学校研究紀要, 22, 101 (1988)

(受付：昭和63年 5 月19日) 